\title{
A Screening Procedure for Repellents against a Sea Snail
}

\author{
Keiichi OHta, Hideaki Matsumoto and Tsutomu NawamaKI \\ Department of Agricultural Chemistry, Shizuoka University, \\ Shizuoka, Japan
}

Received February 9, 1978

\begin{abstract}
A convenient procedure to assay the repellent activities of organic and inorganic substances against a sea snail Monodonta neritoides has been developed. By the use of this procedure, 8 authentic compounds and the benzene extracts of 11 species of plants were found to show such repellent activities.
\end{abstract}

Inorganic copper ${ }^{1)}$ and organic tin compounds ${ }^{3}$ have been commonly used throughout the world to protect ships, fishnets, buoys and other structures in the sea from attaching marine animals (fouling animals). In order to minimize the amount of pollutants in the sea, heavy metallic antifouling agents should be replaced by safer chemicals which are less toxic to mammals and not accumulated in organisms. This necessity prompted us to survey natural products for the presence of repellents against fouling animals.

As part of our investigation, we have recently developed a procedure of detecting repellents against a sea snail Monodonta neritoides (Japanese name, Kurotsukegai), and the activities of a variety of authentic compounds of our laboratory collection and plant extracts have been assayed.

This paper deals with the procedure of the bioassay and results of the screening study.

\section{MATERIALS AND METHODS}

Test animals. Sea snails $M$. neritoides, $8 \sim 10 \mathrm{~mm}$ in shell diameter, were collected from the intertidal zone of the Okuzure coast of Shizuoka City, and left unfed overnight in a glass box which contained a $1-\mathrm{cm}$ depth of seawater.

Assay of repellent activity. The bioassay was carried out at about $25^{\circ} \mathrm{C}$. A test sample was dissolved in ethylacetate, and a glass capillary was used to have $0.2 \mathrm{ml}$ of the solution evenly absorbed into the sample zone on a filter paper (Toyo Filter Paper, No. 2, Toyo Roshi Co., Ltd.), $9 \mathrm{~cm}$ in diameter (Fig. 1). After evaporating the solvent, the filter paper was set at the bottom of a petri dish, $9.5 \mathrm{~cm}$ in diameter, which contained $3 \mathrm{ml}$ of seawater. After $1 \mathrm{~min}, 5$ snails were placed at the center of the filter paper. Touching the surface of the filter paper frequently with their antennae, the snails immediately began to move away from the center. On an inactive sample, all the snails could arrive at the corner of the petri dish within $1 \mathrm{~min}$ across the sample zone (Fig. 2). If no snail could get away from the central area within $15 \mathrm{~min}$, the sample was judged to be active, and the weight $(\mu \mathrm{g})$ of the sample absorbed into $1 \mathrm{~cm}^{2}$ of the sample zone was recorded as the criterion of the repellent activity.

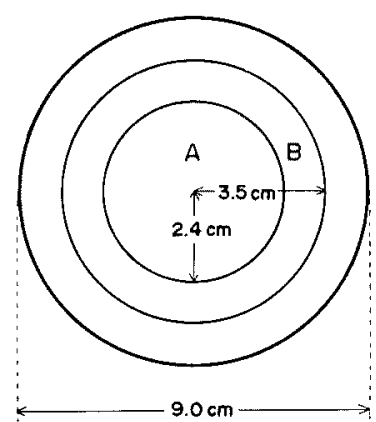

Fig. 1. Filter Paper Used in the Bioassay.

A: Snails were left here at the start. B: Solution of the test sample was absorbed here (sample zone).

Screening procedure for plant extracts. Fresh plant was extracted with benzene for a week at room temperature. After filtration, benzene was evaporated. The residue was dissolved in ethylacetate, and the repellent activity was assayed by the same procedure as described above.

Chemicals. All the chemicals tested were commercially supplied. 


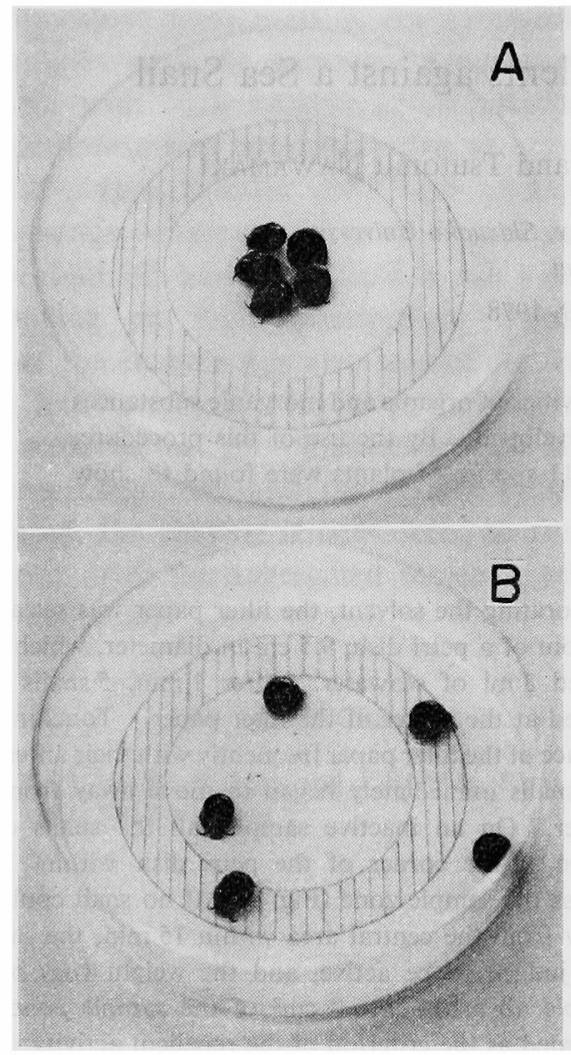

FIG. 2. Response of Snails $M$. neritoides.

The area between the coaxial circles, marked with vertical lines, is the sample zone. A: start of the bioassay. B: an inactive sample; snails could move across the sample zone and arrive at the periphery of the petri dish.

\section{RESULTS AND DISCUSSION}

\section{Repellent activities of authentic compounds}

The activities of 20 fatty acids, 9 aromatic acids and phenols and 8 basic compounds were assayed. As shown in Table I, among a series of fatty acids, enanthic $\left(C_{7}\right), n$-caprylic $\left(\mathrm{C}_{8}\right)$, pelargonic $\left(\mathrm{C}_{9}\right)$ and capric $\left(\mathrm{C}_{10}\right)$ acids were active at the concentration of $50 \mu \mathrm{g} / \mathrm{cm}^{2}$, and the last two even at $30 \mu \mathrm{g} / \mathrm{cm}^{2}$. Benzoic, $p$ coumaric and cinnamic acids showed repellent activities at $50 \mu \mathrm{g} / \mathrm{cm}^{2}$. Basic compounds including basic amino acids were inactive except indole and quinoline which showed activities at $30 \mu \mathrm{g} / \mathrm{cm}^{2}$. Copper (II) sulfate was expected to be a potent repellent because the copper ion had been used as an antifouling agent. A clear repellent activity, in fact, was observed at $5 \mu \mathrm{g} / \mathrm{cm}^{2}$.

Table I. Repellent Activities of Authentic Compounds against a Sea SnaIl $M$. neritoides

\begin{tabular}{|c|c|c|c|c|}
\hline \multirow{2}{*}{ Compounds } & & \multicolumn{3}{|c|}{ Repellent activity at $\left(\mu \mathrm{g} / \mathrm{cm}^{2}\right.$} \\
\hline & & 100 & 50 & 30 \\
\hline \multicolumn{5}{|l|}{ Fatty acids } \\
\hline Propionic & $\left(\mathrm{C}_{3}\right)$ & - & & \\
\hline$n$-Butyric & $\left(\mathrm{C}_{4}\right)$ & - & & \\
\hline Isobutyric & $\left(\mathrm{C}_{4}\right)$ & - & & \\
\hline$n$-Valeric & $\left(\mathrm{C}_{8}\right)$ & - & & \\
\hline n-Caproic & $\left(\mathrm{C}_{8}\right)$ & - & & \\
\hline Isocaproic & $\left(\mathrm{C}_{\mathrm{e}}\right)$ & - & & \\
\hline Enanthic & $\left(\mathrm{C}_{7}\right)$ & + & + & - \\
\hline n-Caprylic & $\left(\mathrm{C}_{8}\right)$ & + & + & - \\
\hline Pelargonic & $\left(C_{9}\right)$ & + & + & + \\
\hline Capric & $\left(C_{10}\right)$ & + & + & + \\
\hline Undecanoic & $\left(C_{11}\right)$ & - & & \\
\hline Laulic & $\left(C_{12}\right)$ & - & & \\
\hline Myristic & $\left(C_{14}\right)$ & - & & \\
\hline Palmitic & $\left(C_{18}\right)$ & - & & \\
\hline Stearic & $\left(C_{18}\right)$ & - & & \\
\hline Oleic & $\left(\mathrm{C}_{18}, \Delta_{1}\right)$ & - & & \\
\hline Linoleic & $\left(\mathrm{C}_{18}, \Delta_{2}\right)$ & + & - & \\
\hline Linolenic & $\left(\mathrm{C}_{18}, \Delta_{3}\right)$ & - & & \\
\hline Arachidic & $\left(\mathrm{C}_{20}\right)$ & - & & \\
\hline Behenic & $\left(\mathrm{C}_{22}\right)$ & - & & \\
\hline \multicolumn{5}{|c|}{ Other acids and phenols } \\
\hline \multicolumn{2}{|c|}{ Benzoic acid } & + & + & - \\
\hline \multicolumn{2}{|c|}{$p$-Coumaric acid } & + & + & - \\
\hline \multicolumn{2}{|c|}{ Cinnamic acid } & + & + & - \\
\hline \multicolumn{2}{|c|}{ Phenol } & + & - & \\
\hline \multicolumn{2}{|c|}{ Catechol } & + & - & \\
\hline \multicolumn{2}{|c|}{ Phloroglucinol } & - & & \\
\hline \multicolumn{2}{|c|}{ Salicylic acid } & + & - & \\
\hline \multicolumn{2}{|l|}{ Ferulic acid } & - & & \\
\hline \multicolumn{2}{|c|}{ Caffeic acid } & - & & \\
\hline \multicolumn{5}{|c|}{ Basic compounds } \\
\hline \multicolumn{2}{|c|}{ Aniline } & - & & \\
\hline \multicolumn{2}{|l|}{ Pyridine } & - & & \\
\hline \multicolumn{2}{|l|}{ Purine } & - & & \\
\hline \multicolumn{2}{|l|}{ Indole } & + & + & + \\
\hline \multicolumn{2}{|l|}{ Quinoline } & + & + & + \\
\hline \multicolumn{2}{|l|}{ Arginine } & - & & \\
\hline \multicolumn{2}{|l|}{ Histidine } & - & & \\
\hline \multicolumn{2}{|l|}{ Ornithine } & - & & \\
\hline \multicolumn{5}{|c|}{ Inorganic compounds } \\
\hline \multicolumn{2}{|c|}{ Copper (II) sulfate } & + & + & + \\
\hline
\end{tabular}

\section{Repellent activities of plant extracts}

Twenty species of terrestrial plants (leaves) and 7 species of seaweeds were collected, and the repellent activities of their benzene extracts 
Table II. Repellent Activities of Benzene Extracts of Plants (Leaves) and Seaweeds AGAINST A SEA SNAIL $M$. neritoides

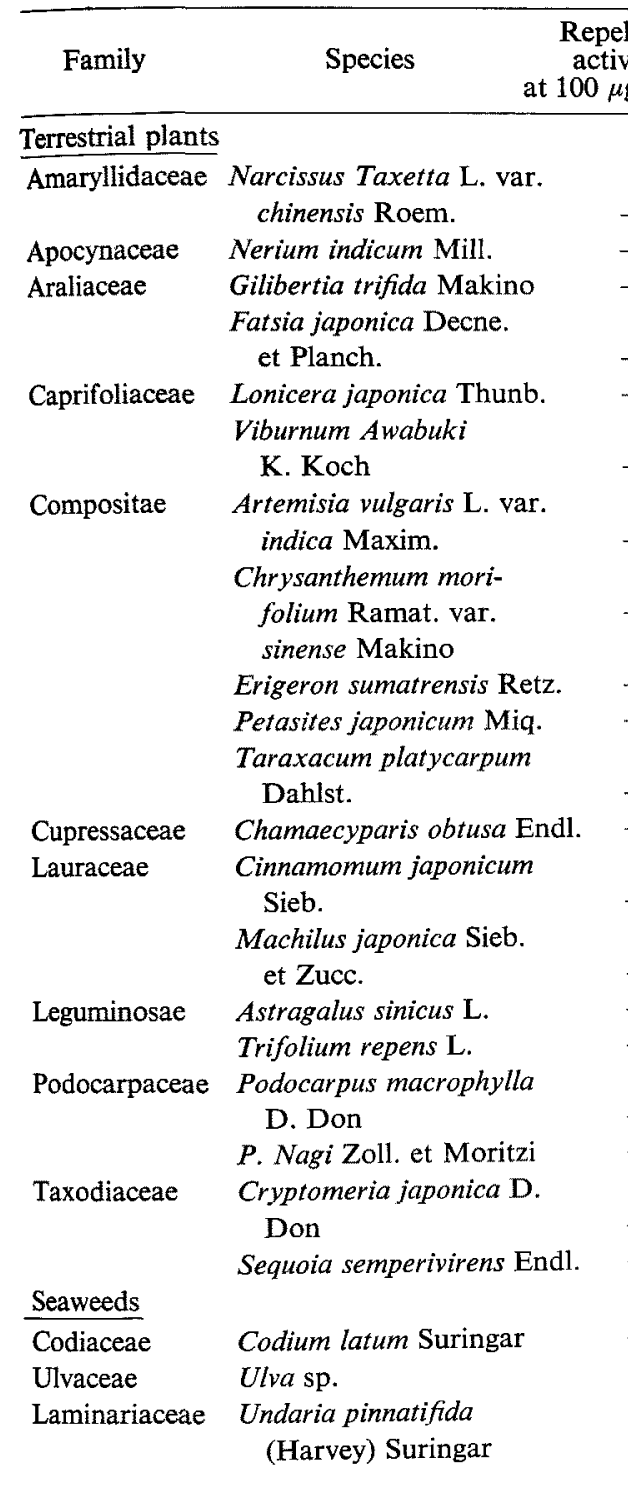

Corallinoideae Marginisporum aberrans (Yendo) Johansen et Chihara

Grateloupiaceae Grateloupia turuturu Yamada

$G$. sp.

Rhodomelaceae Laurencia intermedia Yamada

were assayed at the concentration of $100 \mathrm{ug} / \mathrm{cm}^{2}$. The results are shown in Table II. Among the terrestrial plants, 5 species were active. Notably, all the species of seaweeds except Ulva sp. were active. Active compounds in seaweeds may play the role of attaching or feeding inhibitors against marine animals.

The procedure of the bioassay makes it possible to examine the repellent activities of a number of samples in a short time. The efficacy of the bioassay procedure was evidenced by the discovery of some active authentic compounds and 11 species of plants. The isolation and identification of active principles in plants are in progress.

Acknowledgement. We wish to express our thanks to Dr. T. Habe of the National Science Museum for his identification of the sea snail. We are grateful to Professor M. Saito of this faculty for his identification of terrestrial plants. Thanks are also due to Professor T. Masaki of Hokkaido University, Professor T. Segi of Mie University and Dr. A. Okazaki, formerly a staff member of the Fisheries Agency, for their classification of seaweeds.

\section{REFERENCES}

1) See, for example, cuprous oxide, "The Merck Index,", 9 th"ed., ed. by M.Windholz, Merck \& Co., N. J., 1976,.p. 347.

2) K. Nakagawa, Tosō no Gijutsu, 11, 32 (1976). 